\title{
The Eucharist in Early Franciscan Tradition
}

\begin{abstract}
This paper considers three questions on the Eucharist treated by Alexander of Hales in his Quaestiones disputatae antequam esset frater and Glossa on the Sentences of Peter Lombard, and then by William of Melitona in his Quaestiones de sacramentis and, as the acknowledged author or complier of Book 4 of the Summa Halensis, in that text in its Cologne, 1622 edition: 1. Transubstantiation as the full substantial change of bread and wine on the altar into the body and blood of Christ as opposed to the remanescence and annihilation theories, the other two orthodox alternatives; 2 . How two bodies can occupy the same space at the same time, although one of them, the glorified body of the resurrected Christ, is not held to be subject to the laws of physics governing natural bodies; and 3. How the accidents of bread and wine can survive in the consecrated elements, since they are no longer subtended by the substance of bread and wine. Along with standard authorities, Alexander and William draw on some distinctive sources. These include Peter Lombard's Collectanea, not always distinguished from the biblical Glossa ordinaria by Alexander's and William's editors; the semantic theory of Prepositinus of Cremona; and Innocent III's treatise on the Mass, which defends the Real Presence as transubstantiation in a work otherwise devoted to the liturgy of the Mass. The paper emphasizes the shifting analyses given by Alexander across his two treatments of these questions, as well as those altered by William-moving from semantic to physical to mathematical argumentation-in support of positions on the Eucharist which they shared, but which the Summa Halensis does not adopt.
\end{abstract}

Eucharistic theology has received no lack of attention from historians of scholasticism. Accenting philosophical explanations of the Real Presence doctrine after 1250, they tend to devalue earlier accounts as technically deficient or as confined to divine miracle. This study of Alexander of Hales, William of Melitona, and the Summa Halensis proposes a revaluation of early Franciscan contributions to two major Eucharistic debates. Theologians in their day offered three alternative theories to explain Christ's Real Presence in the Eucharist. Alexander, William, and the authorities on whom they rely all support the transubstantiation theory and reject remanescence and annihilation. This position affected their approach to the second issue, accidents without a subject in the consecrated species. Sources available to Alexander and William in Latin, and their own ingenuity, informed the uses they make of the artes and philosophy. This paper will focus on the modes of argument they apply to these two controverted doctrines.

The characterization of early Franciscans as disinclined to apply rational explanations to the Eucharist can be found even in studies that valorize learning in that 
order. Bert Roest begins with Bonaventure, ${ }^{1}$ as does David Burr. Burr's early Franciscans join Eucharistic theologians whose view of their job 'was not to prove the unprovable or explain the unexplainable'. ${ }^{2}$ While noting that, by 1330, the Franciscan defense of accidents without a subject had become 'an immovable given of metaphysics', William Duba gives no sense of its development before Duns Scotus. Marilyn Adams begins her survey with Aquinas, and is likewise uninterested in early scholastics on the topics she treats. ${ }^{4}$

As is well known, before and after the definition of the Real Presence as transubstantiation at Lateran IV in 1215, three theories were proposed to describe it. All were regarded as tenable within the western orthodox consensus. ${ }^{5}$ Historians have flagged the shift from a largely anti-heretical defense of the Real Presence to its reframing in Aristotelian terms. Indeed, it was the controversy launched by Berengarius of Tours in the $11^{\text {th }}$ century that normalized the language of matter and form, substance and accident, in this context, ${ }^{6}$ Aristotelian terminology accessed by way of Boethius. A standard author in the Latin school curriculum, Boethius remained a major source for the philosophical arguments of Alexander and William as well, along with

1 Bert Roest, "'Franciscan Augustinianism”: Musings about Labels and Late Medieval School Formation,' in Bert Roest, Franciscan Learning, Preaching and Mission, c. 1226-1650: Cum scientia sit donum Dei, armatura ad defendendam sanctam fidem catholicam..., The Medieval Franciscans, 10 (Leiden: Brill, 2016), 111-3, and this despite Roest's vigorous defense of the acceptability of learning from Francis of Assisi onward in Bert Roest, 'Francis of Assisi and the Pursuit of Learning,' in Franciscan Learning, Preaching and Mission, 1-18; Bert Roest, 'The Franciscan School System: Re-assessing the Early Evidence,' in Franciscan Learning, Preaching and Mission, 19-50; and Bert Roest, 'Religious Life in the Franciscan School Network (1 ${ }^{\text {th }}$ Century),' in Franciscan Learning, Preaching and Mission, 51-82. The anthology De causalitate sacramentorum iuxta scholam franciscanum, ed. Willibrord Lampen (Bonn: Petrus Hanstein, 1931) is not of use in this paper; while the editor's selections begin with the Summa Halensis (ascribing its authorship to Alexander) they do not treat the Eucharistic topics here discussed.

2 David Burr, Eucharistic Presence and Conversion in Late Thirteenth-Century Franciscan Thought, Transactions of the American Philosophical Society, 74/3 (Philadelphia: American Philosophical Society, 1984), 6-7.

3 William O. Duba, The Forge of Doctrine: The Academic Year 1330-31 and the Rise of Scotism at the University of Paris, Studia Sententiarum, 2 (Turnhout: Brepols, 2017), 150-3; quotation at 153.

4 Marilyn McCord Adams, Some Later Medieval Theories of the Eucharist: Thomas Aquinas, Giles of Rome, Duns Scotus, and William of Ockham (Oxford: Oxford University Press, 2010).

5 Hans Jorissen, Die Entfaltung der Transsubstantiationslehre bis zum Beginn der Hochscholastik, Münsterische Beiträge zur Theologie, 28/1 (Münster: Aschendorff, 1965), 11-154, 156; Gary Macy, The Theologies of the Eucharist in the Early Scholastic Period: A Study of the Salvific Function of the Sacrament according to the Theologians, c. 1080-c. 1220 (Oxford: Clarendon Press, 1984), 3-5; Gary Macy, 'Berengar's Legacy as a Heresiarch,' in Treasures from the Storeroom: Medieval Religion and the Eucharist (Collegeville, MN: Liturgical Press, 1999), 59-80, Gary Macy, 'The "Dogma of Transubstantiation" in the Middle Ages,' in Treasures from the Storeroom, 82-120; Paul J.J.M. Bakker, La raison et le miracle: Les doctrines eucharistiques (c. 1250-c. 1400): Contribution à l'étude des rapports entre philosophie et théologie, 2 vols. (Nijmegen: Katholieke Universiteit Nijmegen, 1999), 1:156-66; Bakker begins his account with William of Auxerre.

6 Jorissen, Die Entfaltung, 25-44, 156. 
more recent Latin sources and translations. Before continuing, let us note that the investigation in this paper will be limited to printed sources, including, perforce, the uncritical early modern edition of Book 4 of the Summa Halensis. Another limitation is that we will not draw systematically on biblical exegesis as a source, although the scholastics did so. And, despite the terms preferred by some modern scholars, ${ }^{7}$ we will follow our medieval authors in naming the three Real Presence theories: remanescence, annihilation, and transubstantiation.

Proponents of remanescence held that the substance of bread and wine remains in the consecrated species, at least in part, in order to provide a substrate in which the accidents of bread and wine can inhere. Proponents of annihilation held that the bread and wine are totally annihilated by the consecration; God then replaces them with newly created species that contain both Christ's body and blood and the accidents of bread and wine. Both annihilationists and proponents of the complete substantial change of bread and wine into the body and blood of Christ, called transubstantiation since the early twelfth century, had to account for the inherence of the accidents of bread and wine in species that no longer contain the substance of bread and wine. They agreed that such was the case; what they debated was if, and how, it could be explained, beyond the reiteration of biblical and patristic assertions and the appeal to miracle.

Alexander of Hales is rightly hailed for making the commentary on Peter Lombard's Sentences a requirement for incipient university theologians. ${ }^{8}$ Yet, it is remarkable how little attention has been paid to the Lombard's own teachings on the Eucharist as a source for Alexander's. In Peter's Collectanea (first redaction 1139/41, second redaction 1157/58), his commentary on 1 Cor. 11:23-24 defends the transubstantiation theory and formulates a position on accidents without a subject that resonates later. He invokes the Aristotelian language of substance and accidents. 'It is believed', he observes, that [the bread and wine] 'change into the substance of [Christ's] body and blood' (credatur transire in substantiam corporis et sanguinis). Regarding the consecrated species, he maintains that their 'color, taste, shape, and weight, which were accidents of their substance before, ( ... ) may exist without a subject, even as they do in a subject' (color, sapor, forma, pondus, quae prioris sub-

7 Macy, 'Dogma of Transubstantiation,' 83 and passim substitutes 'coexistence', 'substitution', and 'transmutation' while James F. McCue, 'The Doctrine of Transubstantiation from Berengar through Trent: The Point at Issue,' Harvard Theological Review 61 (1968): 385-430 calls the remanescence theory 'consubstantiation' with an evident eye to later Reformation usage; he gives marginal attention to Alexander of Hales and William Melitona as opponents of remanescence.

8 Philipp W. Rosemann, The Story of a Great Medieval Book: Peter Lombard's Sentences, Rethinking the Middle Ages, 2 (Peterborough, Ont.: Broadview Press, 2007), 60-1, although his discussion of Alexander's departures from and amplifications of the Lombard's teachings at 56, 65-9 does not touch on the Eucharist. 
stantiae accidentia fuerunt, ( ... ) dicimus nobis potius videri quod sint sine subjecto quam in subjecto). ${ }^{9}$

While the Lombard does not offer a rationale for these positions in his Pauline exegesis he does so in his Sentences (final redaction 1155/57). He first seeks to shift discussion away from the contrast between the Aristotelian natural changes summarized by Boethius and those wrought by divine miracles with a semantic argument, based on a distinction between literal and metaphorical Eucharistic language drawn from Augustine and confirmed by Ambrose and Eusebius: the term 'body' (corpus) signifies, literally, the invisible body of Christ in the consecrated species; it signifies, metaphorically, the visible elements on the altar. Rather than citing a barrage of biblical references to the Eucharist as if their meaning were transparent, Peter uses this semantic distinction as a hermeneutic tool for interpreting them. ${ }^{10}$ Turning to transubstantiation, again back-stopped by Augustine and Ambrose, the Lombard sides with 'those who say that a substance is changed into a substance, so that the one may become the other essentially' (dicentibus sic substantiam converti in substantiam, ut haec essentialiter fiat illa) and reaffirms that 'the species of [these] things remain the way they were before, both their taste and weight' (species rerum quae ante fuerant remanent, et sapor et pondus). ${ }^{11}$ Rejecting the claim that the elements never change or that their change entails the transubstantiation of the grains and grapes that make bread and wine, ${ }^{12}$ he wields Gregory the Great against their annihilation, insisting that the elements are changed fully and substantially although they retain their accidents. ${ }^{13}$ As Peter explains, given that the substance of the elements has been changed into the substance of Christ's body and blood, in which accidents of bread and wine cannot inhere, 'these accidents therefore remain, subsisting per se' (remanent ergo illa accidentia per se subsistentia) ${ }^{14}$ Both Peter's reference

9 Peter Lombard, In 1 Cor. 11:23-4, in Collectanea in omnes D. Pauli apostoli Epistolas (PL 191:1644BC) for these two quotations. This text, acknowledged to need a critical edition, is held to represent the second redaction. Unless otherwise indicated translations in this paper are my own.

10 Peter Lombard, Sententiae in IV libros distinctae 4, d. 10, cc. 1-2, ed. Ignatius C. Brady, 2 vols, 3rd ed. (Grottaferrata: Collegium S. Bonaventurae, 1971-81), 2:290 - 6. For more on the Lombard and his immediate predecessors on the topics discussed in this paper see Marcia L. Colish, Peter Lombard, 2 vols, Brill's Studies in Intellectual History, 41/1-2 (Leiden: Brill, 1994), 2:552-83.

11 Peter Lombard, Sent. 4, d. 11, c. 1, nn. 1-2 (Brady, 2:296; Peter Lombard, The Sentences, trans. Giulio Silano, 4 vols, Mediaeval Sources in Translation, 42, 43, 45, 48 (Toronto: Pontifical Institute of Mediaeval Studies, 2007-10), 4:54). For more on the consecrated species' retention of taste and weight see Peter Lombard, Sent. 4, d. 12. c. 1 (Brady, 2:304).

12 Peter Lombard, Sent. 4, d. 11, c. 2, nn. 3-4 (Brady, 2:297).

13 Peter Lombard, Sent. 4, d. 11, c. 2, nn. 3-10 (Brady 2:297-9).

14 Peter Lombard, Sent. 4, d. 12, c. 1, n. 1 (Brady, 2:304; Silano, 4:60 (with slight modification)). While Jörgen Vijgen, The Status of Eucharistic Accidents "sine subiecto": An Historical Survey up to Thomas Aquinas and Selected Reactions, Quellen und Forschungen zur Geschichte des Dominikanerordens: neue Folgen, 20 (Berlin: Akademie Verlag, 2013) focuses on Dominicans from Aquinas forward, at 48 he recognizes that Peter Lombard was the first theologian to argue that Eucharistic accidents 
to weight, an accident that is quantifiable, and his argument for the accidents' ability to exist per se, have a notable future ahead of them.

The leading post-Lombardian text to take these arguments in a more analytical direction is the Summa theologiae of the Paris master Prepositinus of Cremona (1195). ${ }^{15}$ In his treatise on the Eucharist and elsewhere Prepositinus tends to ignore positions he disagrees with or to declare that the ones he espouses settle debates which are, in fact, ongoing. Prepositinus omits remanescence and annihilation altogether and confines himself to transubstantiation. His chief contribution lies in his semantics, which takes for granted the theory of signification and supposition that was the last word in Paris. What does 'this' (hoc) mean in the consecration formula 'this is my body' (hoc est corpus meum)? Hoc is a pronoun. Now, nouns and verbs denote things and actions as such, in addition to what they mean in particular statements. Pronouns have meaning only intra-propositionally, in relation to the nouns for which they stand. In this usage, does hoc refer to the bread on the altar? If so, before or after it is consecrated? Does hoc stand for Christ's body? If so, is this pronoun demonstrative or representative? Can it function both ways at the same time? Does it have the same meaning when spoken by Christ at the Last Supper and by a celebrant today? It all depends on the circumstances, says Prepositinus. At the Last Supper, '[Christ] pronounced the blessing, so that it would be understood to denote [his body] both representatively and demonstratively' (et representative et demonstrative ut bis intelligatur dixisse hoc modo: benedixit, dicens ( ... )). Celebrants must consecrate using the correct formula, given by the Lord himself. Yet, at the Last Supper, it was not Christ's words themselves, 'but his secret and spiritual blessing that accomplished it. For he gave these words their power so that it would be accomplished this way in the future' (sed sua secreta et spirituali benedictione hoc fecit. Dedit tamen vim illis verba ut per ea in posterum fieret). ${ }^{16}$

Prepositinus also has strict criteria for the verbs used in statements about Eucharistic change. The elements must not be treated as subjects of active verbs. We must not say that the bread will become the Body of Christ, or that it has become the body of Christ. Statements using verbs in the active voice are unacceptable because they attribute agency to the bread, as if it were able to actualize its own potentialities in the change. It cannot do so. There is no parallel here with a statement

could be self-subsistent and that weight was among the accidents mentioned. He discusses other $12^{\text {th }}$ century figures at $31-64$.

15 For the career of Prepositinus see Marcia L. Colish, ‘Scholastic Theology in Paris around 1200,' in Crossing Boundaries at Medieval Universities, ed. Spencer E. Young, Education and Society in the Middle Ages and Renaissance, 36 (Leiden: Brill, 2011), 32-4. For speculative grammar at the end of the $12^{\text {th }}$ century and its application to theology see Luisa Valente, Logique et théologie: Les écoles parisiennes entre 1150 et 1220 (Paris: Vrin, 2008), 234-72, 333-83.

16 Prepositinus, Praepositini Cancellarii de Sacramentis et de novissimis (Summae theologiae Pars Quarta), ed. Daniel Edward Pilarczyk, Collectio Urbaniana Series 3: Textus ac documenta, 7 (Rome: Editiones Urbanianae, 1964), 77-9; quotation at 77. See the discussion of Prepositinus and others of his generation in Vijgen, Eucharistic Accidents, 71-8. 
such as 'the flour will become bread' (farina erit panis). We must use verbs in the passive voice, since the Eucharistic bread does not act, but is acted upon. Thus, what we must say is that the consecrated bread 'was transubstantiated, so as to be converted' (transubstantiabitur, convertetur). ${ }^{17}$

While Prepositinus notably amplifies the Lombard's appeal to semantics, he uses a less Aristotelian vocabulary in discussing accidents without a subject and undermines Peter's argument for why that condition is possible. Abandoning the idea of Eucharistic accidents as able to subsist per se, Prepositinus holds 'that they exist, miraculously, without a subject' (Dicimus quod miraculose sunt sine subiecto). ${ }^{18}$ So, on that point he takes a backward step, notwithstanding the semantic refinements he elsewhere makes to the Lombard's position.

Pope Innocent III had an accurate grasp of the works of Prepositinus and those of other recent and current scholastics. He had studied theology at Paris from the mid-1170s to the mid-1180s and retained a well-informed and lively interest in the subject. As pope he promoted his former master Peter of Corbeil to the see of Cambrai and then to Sens, and raised to the cardinalate Stephen Langton and Robert of Courçon, fellow-students who became masters in turn. Robert served as papal legate to the University of Paris in 1215, implementing statutes that reflect Innocent's ongoing support of theological education at his alma mater. Innocent had Peter Lombard's Sentences read to him at mealtimes, and was heard to remark, correctly, that those who had attacked that master's Christology had mistaken positions he summarized for those he espoused. Innocent's response, in 1201, to a theological query sent to him by Peter, Archbishop of Compostela, reveals his grasp of the semantic theory currently being taught, and applied to theology, at Paris. ${ }^{19}$

17 Prepositinus, Summa theologiae, 81 and 82 for these quotations. Irène Rosier-Catach, La parole efficace: Signe, ritual, sacré (Paris: Éditions du Seuil, 2004), 360 notes Prepositinus' insistence on verbs in the passive voice but ignores his theological rationale for this usage; here and throughout her discussion of medieval Eucharistic language she processes her authors through the template of speech-act theory, seeing the relevant issue, for them, as the relationship between the speaker's intentions and the efficacy of the words themselves. At 102, Rosier-Catach confines God's role to activating the sacrament's effect in its recipient.

18 Prepositinus, Summa theologiae, 82.

19 Innocent's Parisian education, his knowledge and use of scholastic philosophy and theology, and his promotion of scholastics to high ecclesiastical office have been widely noted. See for example Helene Tillmann, Pope Innocent III, trans. Walter Sax, Europe in the Middle Ages, 12 (Amsterdam: North Holland Publishing Company, 1980), 3, 4-5, 13, n. 46, 299; Christoph Egger, 'Papst Innocenz III. als Theologe: Beiträge zur Kenntnis seines Denken im Rahmen der Frühscholastik,' Archivum Historiae Pontificae 30 (1992): 55-123; Christoph Egger, 'A Theologian at Work: Some Remarks on Methods and Sources in Innocent III's Writings,' in Pope Innocent III and His World, ed. John C. Moore (Aldershot: Ashgate, 1999), 25-33; Spencer E. Young, Scholarly Community at the Early University of Paris: Theologians, Education and Society, 1215-1248, Cambridge Studies in Medieval Life and Thought: Fourth Series, 94 (Cambridge: Cambridge University Press, 2014), 27-8; Matthew Doyle, Peter Lombard and His Students, Medieval Law and Theology, 8; Studies and Texts, 201 (Toronto: Pontifical Institute of Mediaeval Studies, 2016), 68-71; for the debate on the Lombard's Christology see Marcia L. 
Innocent wrote his commentary on the Mass, De sacro altare mysterii libri sex (1195/97), while still a cardinal. This treatise has appealed mainly to scholars writing on the history of its genre or the history of the liturgy. ${ }^{20}$ Indeed, the bulk of the text deals with what we might call the directions for staging a pontifical high Mass, with a detailed discussion of its prayers, their biblical sources and multiple meanings; the celebrant's gestures, vestments, and accoutrements; and the rules for who can celebrate and receive the sacrament. Book 4 of this work treats the Real Presence doctrine. This section of Innocent's treatise is omitted from its modern critical edition and, while described as 'a compendium of scholastic debates concerning the Eucharist', it is often bypassed by historians of Eucharistic theology. ${ }^{21}$ The only full-dress study of Innocent as Eucharistic theologian in this work is descriptive rather than analytical. ${ }^{22}$ But Innocent's use of his sources, the positions he defends, and his influence on Alexander of Hales and William of Melitona merit, and reward, further attention.

Innocent draws on both the Lombard and Prepositinus. With the Lombard, he leads off with transubstantiation before critiquing remanescence and annihilation. While he does not disdain the appeal to miracle in the Eucharistic change, he takes to heart Prepositinus' semantic strictures, confining himself to verbs in the passive voice in describing it: 'The matter of the bread or wine is changed into the substance of [Christ's] flesh and blood, ( ... ) transubstantiated into [his] body' (materia panis vel vini mutatur in substantiam carnis et sanguis, (... ) transsubstantiatur in corpus). He also agrees with the Lombard that this substantial change is total and permanent. ${ }^{23}$

Colish, 'Christological Nihilianism in the Second Half of the Twelfth Century,' in Marcia L. Colish, Studies in Scholasticism (Aldershot: Ashgate, 2006), ch. 15.

20 Gary Macy, 'Commentaries on the Mass during the Early Scholastic Period,' in Treasures from the Storeroom (see above, n. 5), 142-71 with the section on Innocent's work at 154-6; Anko Ypenga, 'Innocent III's De missarum mysteriis Reconsidered: A Case Study on the Allegorical Interpretation of Liturgy,' in Innocenzo III: Urbs et orbis: Atti del congresso internazionale, Roma, 9-15 settembre 1998, ed. Andrea Sommerlechner, 2 vols, Nuovi Studi Storici, 55 (Rome: Nella sede dell'Istituto, Palazzo Borromini, 2003), 1:332-9. Cf. the dismissive view of John C. Moore, Pope Innocent III (1160/611216): To Root up and to Plant, Medieval Mediterranean, 47 (Leiden: Brill, 2003), 22; for Moore, this is Innocent's 'most problematic' work because it has nothing to say on church governance or current politics.

21 Macy, 'Commentaries on the Mass,' 156; cf. David F. Wright, 'A Medieval Commentary on the Mass: Particulae 2-3 and 5-6 of the De missarum mysteriis (ca. 1195) of Cardinal Lothar of Segni (Pope Innocent III),' (PhD thesis, University of Notre Dame, 1971).

22 Michele Maccarrone, 'Innocenzo III teologo dell'Eucharistia,' in Michele Maccarrone, Studi su Innocenzo III, Italia sacra, 17 (Padua: Antenore, 1972), 341-431.

23 Innocent III, Mysteriorum evangelicae legis et sacramenti eucharistiae libri sex 4.7 (PL 217:860D861 A) for the quotation; see also Innocent III, Mysteriorum evangelicae 4.7 (PL 217:859C-861 A) for the use of passive verbs and Innocent III, Mysteriorum evangelicae 4.9 (PL 217:862C) for the permanence of the change. 
The body and blood of Christ fully inhabit all hosts and their fragments, Innocent argues, contra the remanescence theory. He offers an analogy in support of this point. We can see our entire image in a mirror when the mirror is whole and in its fragments if it is broken. While not noting the limits of this analogy, Innocent admits that, since all bodies, resurrected or not, have physical boundaries, he has no response to the objection that no body can be in two places at once. ${ }^{24}$

In a maneuver that proves influential, Innocent yokes the ability of accidents to exist without a subject to the attack on the annihilation theory. There is no need to posit the utter destruction of the elements and their miraculous recreation de novo. Anyhow, even if recreated this way, they will still have accidents without a subject. Not to worry; the Lombard has solved this problem, and Innocent agrees: 'But after the consecration, an accident exists without a subject, since it exists per se, for the substance indeed changes but the accident remains' (Sed post consecrationem accidens est sine subjecto, quoniam existit per se, transit enim substantia, sed remanent accidentia). Without naming any of the Lombard's self-subsistent accidents, Innocent concludes that, while none of the Aristotelian-Boethian modes of natural change account for transubstantiation, that entire line of argument can be dismissed given the capacity of the transubstantiated species to retain their accidents. ${ }^{25}$

Innocent laments that controversialists conduct Eucharistic debates 'more subtly than usefully' (subtiliter magis quam utiliter); ${ }^{26}$ but more is in store, including developments stemming from his own influence on Alexander of Hales, the true founder of early Franciscan thought on the Eucharist. Alexander's teaching survives in two texts, his Quaestio 51 on the Eucharist, found among his disputed questions (1220/ 36), and in Book 4 of his Glossa on the Sentences (1223/25). Both were written before he became a Franciscan. Although his editors make no attempt to date individual quaestiones, internal evidence suggests that Quaestio 51 predates the Glossa, which is how we will treat it here.

Quaestio 51 rarely cites Alexander's sources expressly. He does quote and attribute the Lombard's general definition of sacrament. ${ }^{27}$ But, without naming remanescence or annihilation, he aligns himself with the Lombard's critique of both positions. Alexander also amplifies Prepositinus' semantic arguments. At times he also takes an independent line. In a remark not found in his sources, he chides predeces-

24 Innocent III, Mysteriorum evangelicae 4.8 (PL 217:861B-861C).

25 Innocent III, Mysteriorum evangelicae 4.9 (PL 217:861D-862C); quotation at 862B. For the critique of natural modes of change see Innocent III, Mysteriorum evangelicae 4.20 (PL 217:870 A-871D). Innocent on the survival of accidents is noted by Vijgen, Eucharistic Accidents, 66, with a good general discussion of his position at 64-9.

26 Innocent III, Mysteriorum evangelicae 4.20 (PL 217:870C).

27 Alexander of Hales, Quaestio 51, d. 1, m. 2, nn. 9-12, in Magistri Alexandri de Hales Quaestiones disputatae "Antequam esset frater", 3 vols, Bibliotheca Franciscana Scholastica Medii Aevi, 19-21 (Quaracchi: Collegium S. Bonaventurae, 1960), 2:894-97, citing Peter Lombard, Sent. 4, d. 8, c. 7 (Brady, 2:284-6). 
sors, who do not always get everything right, with focusing so much on the Eucharistic bread that they slight the wine. ${ }^{28}$ While ignoring debates on Eucharistic liquids that did exist, Alexander asserts that, had he willed to do so, Christ could have transubstantiated himself into an element other than bread. ${ }^{29}$

Following the Lombard and Prepositinus, Alexander's main argument in Quaestio 51 starts with transubstantiation and treats the semantic propriety of statements about the Eucharist before moving on to remanescence and annihilation. Should we say that the bread becomes the body of Christ? Or that the bread will become the body of Christ? Alexander firmly rejects statements that would give agency to the elements. Thus, we must say that 'the bread is changed into the body of Christ' (panis mutatur in corpus Christi). We must not say that 'the bread makes the body of Christ' (panis fit corpus Christi) but must say that 'what was bread is the body of Christ' (quod fuit panis est corpus Christi) when it is consecrated..$^{30}$ At the same time as he applies these semantic rules, Alexander agrees with Prepositinus that it is not the words themselves but Christ's power that effects the Eucharistic change. ${ }^{31}$

Against the remanescence theory Alexander's Quaestio 51 joins the Lombard and Innocent in stressing that the Eucharistic change is both real and full. Against the annihilation theory he agrees that, since the accidents of bread and wine remain, the elements are not totally annihilated. Citing and dismissing an analogy proposed by some defenders of remanescence, that of light which can pass through glass without changing either the glass or itself, he wraps up his critique of both positions, asserting that the accidents indeed remain unchanged, while the substance of the elements is thoroughly changed, from an unglorified to a glorified state. ${ }^{32}$

This brings Quaestio 51 to the theme of accidents without a subject. Alexander takes the self-subsistent accidents of the Lombard and Innocent in a new direction. While Alexander uses the term 'marvelous' (mirabile) to describe it, he treats this situation as grounded in natural reality, obviating the need to explain it purely as a miracle. He cites Basil, not mentioned by the Lombard or Innocent in this connection: while we can think about accidents distinct from substance, as abstract ideas, what we can only conceptualize, God can do. But the situation in the consecrated elements is not abstract, says Alexander. It is de facto. 'An accident,' he as-

28 Alexander of Hales, Quaestio 51, d. 1, m. 5, nn. 25-6, 2:903-4. For debates on the substitution of other liquids for wine see Gary Macy, 'Mediterranean Meals to Go: Early Encounters with Nonvinous Cultures,' Worship 92 (2018): 12-27, although this study does not include Alexander. My thanks to Prof Macy for this reference.

29 Alexander of Hales, Quaestio 51, d. 6, m. 8, nn. 191-4, 2:462-3.

30 Alexander of Hales, Quaestio 51, d. 3, m. 1, n. 60, 2:916 for his posing of these questions and d. 3, m. 4, nn. 95-6, 2:930-1 and d. 6, m. 7, nn. 189-90, 2: 960-2 for his answers; quotations at d. 3, m. 4, n. 97, 2:931.

31 Alexander of Hales, Quaestio 51, d. 6, m. 7, nn. 189-190, 2:960-2.

32 Alexander of Hales, Quaestio 51, d. 3, m. 1, nn. 61-76, 2:917-23; d. 3, m. 2, nn. 77-89, 2:924-28; d. 4, m. 2, nn. 112-7, 2:936-8. Alexander raises and dismisses as a non-question the issue of 'how much Christ' is present in the consecrated elements at d. 5, m. 1, n. 29, 2:941-4. 
serts, 'sometimes has its own kind of being, according to its own essence, which does not depend on a subject. ( ... ) Thus, even if the substance of bread should be destroyed, its quantity is not destroyed' (Accidens habet quoddam esse secundum suam essentiam quod non dependet a subiecto. ( ... ) Licet ergo panis substantia destruatur, quantitas tamen non destruitur). Here Alexander moves from the Lombard's accident of weight, listed along with other, non-quantitative accidents, and focuses on quantity alone. This is an innovation for which Alexander is rightly credited, if it is not always recognized as an extension of the Lombard's teaching. ${ }^{33}$

Alexander enriches the above arguments in his Glossa. In this work he is much more inclined to cite authorities, beyond those who, like Augustine, are not named but absorbed via the Lombard's assimilation of them. Along with the Lombard himself and Peter's own patristic sources he cites Basil, whom we have met and will meet again, Jerome, and Ambrose. He also cites later authors, including John Damascene, whom the Lombard had introduced into Latin theology, Hugh of St Victor, Peter of Poitiers, Peter Comestor, Bernard of Clairvaux, and Gratian. Some are contemporaries cited by the Lombard, if not on the Real Presence; others wrote after his day. ${ }^{34}$ Most of the philosophy Alexander invokes, pro or con, comes from Boethius, not from new Greco-Arabic translations. The Latin source he cites most frequently is Innocent III. ${ }^{35}$ A content-analysis of his Innocent citations, however, shows that few of them come from Book 4 of the pope's treatise on the Mass. The vast majority of them deal with liturgical and administrative matters found elsewhere in that text. On these

33 Alexander of Hales, Quaestio 51, d. 3, m. 1, n. 74, 2:922; d. 4, m. 3, nn. 18-27, 2:938-41 for these successive quotations. Vijgen, Eucharistic Accidents, 83-6, 354 hails this innovation; but he thinks that Quaestio 51 post-dates the Glossa although his discussion of the latter text shows that it gives a fuller account of this doctrine. Vijgen does not connect it either with the Lombard's account of accidents without a subject or with Alexander's critique of nihilianism. Cf. Bakker, La raison et le miracle, 1:293-4, who notes that most subsequent scholastics follow the Lombard on the accidents of taste and weight. At 1:302-4 Bakker presents Alexander's position as quite close to that of Aquinas, framing this idea in terms of the distinction of essence and existence. He does not discuss the influence of the argument he ascribes to Alexander on William of Melitona or the Summa Halensis. 34 Alexander of Hales, Magistri Alexandri de Hales Glossa in quatuor libros Sententiarum Petri Lombardi, 4 vols, Bibliotheca Franciscana Scholastica Medii Aevi, 12-5 (Quaracchi: Collegium S. Bonaventurae, 1951-7), e.g. 4, d. 8, a. 8, 4:139; d. 11, a. 9, 4:176 (Hugh and Jerome: No post-Last Supper Eucharists were celebrated until after the Crucifixion); d. 10, a. 9, 4:165 (Ambrose: Transubstantiation occurs fully); d. 11, a. 5, 4:173-4 (Hugh and Damascene: Against annihilation); d. 11, aa. 1-2, 4:168-70 (Peter of Poitiers and Bernard of Clairvaux: Transubstantiation as a miracle); d. 11, aa. 3-4, 4:170-1 (Peter Comestor: When, during the pronunciation of the consecration formula, the Eucharistic change occurs); d. 11, a. 2, 4:170 (Damascene: Why there are two species); d. 13, a. 5, 4:201-3 (Gratian: Communion denied to excommunicates). This selection does not exhaust the list. 35 On Alexander's role in putting Innocent on the scholastic agenda but without a content-analysis of his use of his work see Jorissen, Die Entfaltung, 34-6, 43-4; Maccarrone, 'Innocenzo III,' 399; Gary Macy, 'Reception of the Eucharist according to the Theologians: A Case of Diversity in the $13^{\text {th }}$ and $14^{\text {th }}$ Centuries,' in Treasures from the Storeroom (see above, n. 5), 37. 
topics Alexander usually agrees with Innocent. ${ }^{36}$ The most foundational theological idea he credits to Innocent concerns the manifestation of Christ's divine nature: as a Trinitarian person Christ manifests divine ubiquity in the creation, by essence. He manifests his divinity to the just, by grace. He manifests his divinity in union with his humanity, by incarnation. This union of divinity and humanity in the incarnate Christ has three modes: it exits 'locally, in heaven; personally, in the Word; and sacramentally, on the altar' (localiter in caelo, personaliter in Verbo, sacramentaliter in altari). ${ }^{37}$ Stated at the opening of the Glossa's treatise on the Eucharist, this is a theme to which Alexander returns.

Despite his reliance on Innocent there are issues on which Alexander departs from him. He expressly dismisses Innocent's mirror analogy, citing Aristotle as his counter-authority. This analogy, he notes, fails to address a larger objection to transubstantiation, the inability of two bodies to occupy the same space at the same time. Alexander proposes an alternative: Christ's Real Presence in multiple hosts, or parts of hosts, 'is not contained spatially, as if one part could be assigned here and another part there, parts according to places, but definitively' (non continetur situaliter, ut sit assignare hanc partem ibi et hanc partem hic, secundum partes loci, sed definitive). What is definitive here is the divine nature united to Christ's glorified human body. It is this divine nature that enables him to make his body present simultaneously in all Eucharistic elements and parts of them. Here, Alexander makes a key distinction: divine ubiquity as the enabling condition of the Eucharistic Real Presence is specific to that sacrament. It should not be confused with divine ubiquity in its most general sense. ${ }^{38}$ In effect, on this topic Alexander uses one of Innocent's positions, which he supports, to correct another of Innocent's positions, which he rejects.

In the Glossa Alexander also treats as discussion-worthy a subject declared closed by Innocent, the mandatory use of wine in the Eucharist, compensating here for the inattention to wine that bemuses him in Quaestio 51. Alexander takes seriously those who consider whether another liquid might be substituted if wine is unavailable. Alexander shares with Innocent the consensus on concomitance, which views the body and blood of Christ as equally present in each of the consecrated species. That said, there is real merit in the proposal that, where wine is lacking, the best course of action would be to administer the Eucharist via the host alone.

36 Alexander of Hales, Glossa 4, d. 8, a. 5, 4:135-6; d. 8, aa. 12-6, 4:143-6; d. 11, a. 13b, 4:178; d. 11, aa. 15-6, 4:179-80; d.11, aa. 20-2, 4:183-4; d. 12, a. 4, 4:190-1; d. 12, a.11, 4:196; d. 13, a. 3, 4:200; d. 13, aa. 9-10, 4:204-6. The issues here are mostly directives to celebrants and include the use of the liturgical consecration formula despite variations in the New Testament references to it; the need to approach the Eucharist fasting although it was received at the end of a meal at the Last Supper; the mandatory use of unleavened bread, wine, and water; the frequency of Eucharistic celebrations; who is qualified to celebrate; and why the reasons for offering a sacrifice are perfected in the Eucharist. 37 Alexander of Hales, Glossa 4, d. 8, a. 4, 4:134.

38 Alexander of Hales, Glossa 4, d. 10, a. 4, 4:155; d. 12, a. 9, 4: 193-5; quotation at d. 12, a. 9, 4:193. 
Having aired both the rule Innocent presents as non-negotiable and these other, more practical, options, Alexander admits that he remains undecided on this still open question. ${ }^{39}$

Turning to Alexander's defense of transubstantiation and critique of remanescence and annihilation, he shares with the Lombard and Prepositinus a concern with semantics, upgrading their analyses. Here too, semantic specifications preface what follows. Alexander refers expressly to the supposition theory presupposed by Prepositinus. Defending Christ's Eucharistic ubiquity, Alexander argues that we cannot say 'this man is everywhere' (iste homo est ubique) when homo supposits a man like us. We say 'this man' (iste homo) when we simply supposit a particular individual. But, in speaking of the Eucharist, when we say iste homo what we supposit circumscriptively (per circumscriptione) is Christ, the man now in heaven, whose divinity exempts his glorified humanity from the limits of an earthly body. ${ }^{40}$ Alexander presents this innovative application of supposition theory as another way of shortcircuiting the objection that two bodies cannot occupy the same space at the same time: "For when "this man" is said [of Christ], what is referred to is the person to whom human nature is joined' (Cum enim dicitur 'iste homo' dicitur persona cui humana natura est unita). ${ }^{41}$ Alexander's use of persona here is pointed, referring to Christ as a member of the Trinity.

Alexander also follows Prepositinus on verbs and on parts of speech whose meaning depends entirely on their reference to other parts of speech. Since the Eucharistic elements have no agency, he agrees, we must not say that 'the bread can be the body of Christ' (panis potest esse corpus Christi) but must say 'the bread is transubstantiated' (panis transsubstantiatur). ${ }^{42}$ Moving on to prepositions such as ex and de, Alexander notes that de can refer to the matter from which something derives, as in the statement that the body of Christ was made 'from the Virgin's flesh' (de carne Virginis). De can refer to the power that makes something happen (potestativum), as when we say that Christ was conceived 'by the Holy Spirit' (de Spiritu Sancto). In the Eucharist, de or ex refers to the entity out of which something is changed into something else (conversivum). Aristotle's Metaphysics supports this analysis, says Alexander: When a change is signified by the use of $e x$, this preposition refers to its terminus a quo. ${ }^{43}$ With Prepositinus, Alexander concludes that, notwithstanding these semantic clarifications, the virtus of the Eucharistic consecration lies not in

39 Alexander of Hales, Glossa 4, d. 11, a. 12, 4:177-8; d. 11, a. 15, 4:179-80. On the development of the doctrine of concomitance and the communion of the laity via the host alone, not controversial at this time, see James J. Megivern, Concomitance and Communion: A Study of Eucharistic Doctrine and Practice, Studia Friburgensia, 33 (Fribourg: The University Press, 1963). For debates on the use of liquids other than wine see Macy, 'Mediterranean Meals to Go,' 12-27.

40 Alexander of Hales, Glossa 4, d. 10, a. 4, 4:156.

41 Alexander of Hales, Glossa 4, d. 10, a. 5 h, 4:159.

42 Alexander of Hales, Glossa 4, d. 10, aa. 10-1, 4:165-6.

43 Alexander of Hales, Glossa 4, d. 10, a. 10, 4:166. 
the words used but in the spiritual power imparted to them by Christ. ${ }^{44}$ Words are signs, as are the bread and wine of the Eucharist, and we must grasp the difference between what pertains to the sacrament as a sign (significationis) and the power of Christ which pertains to it as its cause (causalitatis).

The causative role enabling Christ to inhabit fully the Eucharistic elements informs Alexander's framing of the Lombard's and Innocent's argument against remanescence: 'All of the bread, both in its matter and form' (totius panis constantis materia tali et forma) undergoes 'a transmutation which is completed in its becoming the body of Christ' (transmutationem quae terminatur ad esse corpus Christi); no 'substance of bread' (substantia panis) remains. ${ }^{45}$ Alexander makes the same point against nihilianism: the consecration 'achieves a conversion that applies to the whole substance, matter, and form, the accidents remaining' (manent accidentia et fit conversio secundum totam substantia: materiam et formam). Thus, it is incorrect to say that the elements are completely annulled and newly recreated as Christ's body and blood with their accidents intact. For the accidents were not annulled by the elements' transubstantiation. ${ }^{46}$

This brings Alexander to the issue of accidents without a subject. He reviews the accounts of natural change listed by Aristotle and Porphyry by way of Boethius. He agrees that they do not apply to the Eucharist. The Glossa develops Alexander's own earlier treatment of the Lombard on self-sufficient accidents. He repeats Basil's remark that God can separate substance and accident in fact while we can only distinguish them as abstract ideas. But the weight of his argument falls on the per se existence of the accident of quantity. He compares quantity with other accidents. Not all accidents can exist per se. For instance, color is not self-subsistent. It only exists as an attribute of a figure. But figure exists only with respect to quantity (figura autem in quantitatem). And 'it is suitable that quantity, which is closer to substance than are many kinds of accidents, receives its own property, by divine power, as if it were a substance' (quantitas autem, eo quod de genere accidentium propinquior est substantiam, convenit enim in pluribus, ex virtute divina, recepit proprietatem eius quod sit substantia). Quantity is even closer to substance than abstract attributes like panitas and vinitas; for, as with other accidents, they 'remain properties subor-

44 Alexander of Hales, Glossa 4, d. 8, a. 7, 4:137-8.

45 Alexander of Hales, Glossa 4, d. 10, a. 9, 4:165; see also d. 11, a. 1, 4:168-70; d. 11, a. 6, 4:173-4. On the sacrament as sign or symbol see also Alexander of Hales, Glossa 4, d. 8, a. 11, 4:142-7; d. 9, a. 5, 4:150 -1; d. 10, a. 5, 4:156 - 9 and the discussions of Damien Van den Eynde, Les définitions des sacraments pendant la première période de la théologie scolastique (1050-1240) (Rome: Antonianum, 1950), 130 - 3 and Macy, 'Reception of the Eucharist,' 37-9; Gary Macy, 'The Theology of the Eucharist in the High Middle Ages,' in A Companion to the Eucharist in the Middle Ages, ed. Ian Christopher Levy, Gary Macy, and Kristen Van Ausdall, Brill's Companion to the Christian Tradition, 26 (Leiden: Brill, 2012), $380-2$.

46 Alexander of Hales, Glossa 4, d. 10, a. 9, 4:165; d.10, a. 12, 4:167; d. 11, a. 1, 4:168-70; d. 11, aa. 5-6, 4:173-4; quotation at d. 11, a. 1b, 4:169. Noted by Bakker, La raison et le miracle, 1:64-5. 
dinate' to quantity (remanent proprietates consequentes)..$^{47}$ Thus, for Alexander, while divine power is involved, the kind of divine power involved looks to be God's endowment of the accident of quantity with its own essential properties, rather than his suspension of the laws of nature. And, for Alexander, not only does quantity have the basic capacity to exist per se, its quasi-substantial essence also enables it to subtend the other accidents in the consecrated species.

In our early Franciscan story Alexander's most important disciple is William of Melitona, Parisian regent master from 1247 to 1253. His De sacramento altaris, one of William's Quaestiones de sacramentis (1245/47), advances Alexander's teaching appreciably. William is also the recognized author of Book 4 of the Summa Halensis, left incomplete by his death (1257/60), discussed below. While earlier scholars accent William's interest in the liturgy of the Mass, a recent work flags his contribution to the theme of accidents without a subject. ${ }^{48}$ That topic is extremely important. But other facets of William's work also need comment.

An underappreciated area is William's concern with semantics. On some issues he seconds Alexander and Prepositinus; on others he omits their rules; on still others he adds new arguments. Among the latter, William notes that the nouns 'bread' and 'wine' are comparable to names such as 'Marcus' and 'Tullius', which denote the same individual and not two different essences. Thus, two concomitant species comprise a single sacrament. ${ }^{49}$ William supports Alexander's analysis of the prepositions ex and de and agrees with him and Prepositinus in banning locutions that grant agency to Eucharistic elements. Thus, we must not say that the consecration 'makes the body of Christ from bread or by bread' ('ex pane' vel 'de pane' fit corpus Christi) or that 'the bread makes or can be the body of Christ' (panis fit corpus Christi;

47 Alexander of Hales, Glossa 4, d. 11, a. 1, 4:169-70; d. 12, a. 1, 4:185-7; quotations at d. 12, a. 1f, 4:187. Bakker, La raison et le miracle, 1:302-4, assimilates Alexander on this topic to its treatment by Aquinas, presenting the latter's position as its real beginning.

48 The older view ascribing authorship of the Summa Halensis to Alexander, as in Hugo Dausend, 'Das opusculum super Missam des Fr. Wilhelm von Melitona und die entsprechenden Stellen in der Summa theologica Alexanders von Hales,' in Aus der Geisteswelt des Mittelalters: Studien und Texte Martin Grabmann zur Vollendung des 60. Lebensjahres von Freunden und Schülern gewidmet, ed. Albert Lang, Josef Lechner, and Michael Schmaus, 2 vols, Beiträge zur Geschichte der Philosophie und Theologie des Mittelalters, Supplementband 3 (Münster: Aschendorff, 1935), 1:554-77, was corrected by Victorin Doucet, 'The History of the Problem of the Authenticity of the Summa,' Franciscan Studies 7 (1948): 26 - 41. For William's recourse in the Summa Halensis to Innocent III's treatise on the Mass, held to be more extensive than that of any other medieval author but without content-analysis, see Jorissen, Die Entfaltung, 42-3; Maccarrone, 'Innocenzo III,' 399-400. For William on accidents without a subject see Vijgen, Eucharistic Accidents, 87-94.

49 William of Melitona, De sacramento altaris [=tr. 4], p. 2, q. 5, cc. 17-8, in Guillelmi de Militona Quaestiones de sacramentis, ed. Gedeon Gál, 2 vols, Bibliotheca Franciscana Scholastica, 22-3 (Quaracchi: Collegium S. Bonaventurae, 1961), 2:530 -1. For more on concomitance see William of Melitona, De sacramento altaris, p. 6, q. 30, 2:640-1; p. 7, q. 39, 2:677-8. 
(... ) panis potest esse corpus Christi). ${ }^{50}$ But William does not comment on his predecessors' pendant rule requiring the use of verbs in the passive voice to describe the elements' change.

William returns to Prepositinus on the supposition of hoc but applies a less adept analysis to the est and corpus in the consecration formula. As a pronoun, he agrees, hoc supposits only in relation to the intra-propositional noun for which it stands. It can supposit its noun simply or demonstratively. It would be a 'false locution' (oratio falsa) to say that hoc means 'the substance or accidents of the bread' (substantia panis vel accidens). What hoc actually supposits in the consecration formula is the transubstantiated body and blood of Christ. ${ }^{51}$ Moving on to est, William admits that, as a present indicative verb, est denotes what currently is, not what has just changed. He posits a parallel with 'I baptize you' (Ego te baptizo), in which the present indicative verb refers to a status-changing event. He elides the lack of a parallel substantial change in the baptismal water. Still, the unhappy warrant he offers for both formulae is God's creative 'Let there be light' (fiat lux), denoting an event that is at once brought about. William recognizes that the fiat of Gen. 1:3 is not an indicative verb but an imperative. ${ }^{52}$ Leaving that problem unresolved, he asks why the consecration formula requires corpus rather than caro to denote Christ's body, since the Bible uses both terms. What William likely has in mind is John 1:14: 'The Word was made flesh' (Verbum caro factum est). Well, he observes, arguing here from connotation not supposition theory, corpus can also means corpse, reminding us that Christ accepted death on the cross. And a corpus is also a corporation, or a collection whose constituents have something in common; this is the sense of corpus as applied to the church. ${ }^{53}$ While these lucubrations on est and corpus are less wellhoned than the arguments William and his predecessors derive from speculative grammar, he agrees that it is not Eucharistic language, however apposite, but the virtus of Christ, that effects transubstantiation. ${ }^{54}$

50 William of Melitona, De sacramento altaris, p. 7, q. 35, c. 5, 2:660; p. 7, q. 40, cc. 1-2, 2:679-80 for these successive quotations with more on the theme at 4:680-3; see also William of Melitona, De sacramento altaris, p. 7, q. 35, c. 11, 2:661-2. For a similar argument on the use of hoc and est in the transubstantiation of the wine see William of Melitona, De sacramento altaris, p. 4, q. 21, cc. 1-13, 2:597-601. Rosier-Catach, La parole efficace, 319-23, 377, 381-2, 417-22, 473 notes William on hoc, although not on ex and de, but without mention of his application of supposition theory, and also his ban on statements that would give agency to the Eucharistic elements, but without mention of the theological rationale for it that he shares with Prepositinus and Alexander.

51 William of Melitona, De sacramento altaris, p. 4, q. 15, cc. 1-15b, 2:580 - 6; quotations at c. 4, 2:581 and c. 6, 2:582.

52 William of Melitona, De sacramento altaris, p. 4, q. 16, cc. 1-15, 2:586-9. Rosier-Catach, La parole efficace, 389, 391 notes that William recognizes that the would-be fiat analogy is a problem he does not solve, but highlights it as the closest he comes to anticipating a speech-act.

53 William of Melitona, De sacramento altaris, p. 4, q. 17, cc. 1-8b, 2:590-92. Noted by Rosier-Catach, La parole efficace, 418, but without reference to William on corpus.

54 William of Melitona, De sacramento altaris, p. 5, qq. 22-3, 2:601-8. 
William often cites Innocent III, indeed, more frequently than Alexander, but in different contexts. Innocent is William's authority of choice on the reception of communion. Other than that, he quotes Innocent on one linguistic issue: the words following the celebrant's 'this is my body' are canonical but do not accomplish the Eucharistic change. ${ }^{55}$ William ascribes to Innocent Augustine's point, by way of the Lombard, that Christ's presence in the sacrament is real and not metaphorical. ${ }^{56}$ He cites Innocent on the full presence of Christ in every Eucharist and parts thereof, with no reference to the mirror analogy rejected by Alexander, and on the argument that the bread and wine are not totally annihilated since their accidents remain. Unlike Alexander, William expressly criticizes Innocent on accidents without a subject because Innocent appeals to miracle alone. ${ }^{57}$ Indeed, William's own account of accidents without a subject, his most original contribution to Eucharistic theology, yields a new argument drawn from philosophy and mathematics as well as a spirited claim for the role of reason in Eucharistic theology.

William tackles accidents without a substance twice. Dismissing the relevance to the Real Presence of a parts-and-wholes analysis, he makes a general observation: some aspects of the sacrament are natural; others are above reason. But some of the latter can also be understood in natural terms. In natural bodies, substances have accidents. In the consecrated species, 'certain accidents, such as color, taste, and roundness, exist there supernaturally without a subject, without substance: above nature, but not above understanding. For the mind understands accidents without a subject by abstraction' (supra naturam sunt ibi accidentia sine subiecto, ut color, sapor, rotunditas, sine substantia. Hoc autem est supra naturam, sed non supra intellectum; intelligit autem intellectus accidentia sine subiecto per abstractionem). The key abstract idea in this case is quantity, an attribute possessed by the species and, he adds, by Christ's glorified body as well. Quantity is an intrinsic attribute of bodies as such, shared by bodies that change into other bodies although their other attributes differ. In this passage William sees the commensurability of these two abstract accidents of quantity as occurring 'above nature and marvelously' (supra naturam et mirabiliter). ${ }^{58}$

But is it above rational understanding? In another passage William argues that such is not the case. He repeats that quantity is the prime accident of the elements both before and after the consecration, as it is in the glorified body of Christ. But he

55 William of Melitona, De sacramento altaris, p. 4, qq. 18-9, 2:592-5.

56 William of Melitona, De sacramento altaris, p. 6, q. 31, c. 6, 2:642-3; q. 33, c. 6, 2:650-3; q. 33, c. 6 g, 2:652-3; q. 33, c. 7, 2:653; q. 34, c. 3, 2:656-7.

57 William of Melitona, De sacramento altaris, p. 6, q. 27, c. 7, 2:630; q. 32, c. 5, 2:646; p. 7, q. 35, c. 16, 2:663; q. 35, c. 24, 2:666. Cf. Bakker, La raison et le miracle, 1:21-3, 32 who thinks that William subscribes to Innocent's mirror analogy, a citation not found in William's text.

58 William of Melitona, De sacramento altaris, p. 6, q. 32, c. 5, 2:646. For Burr, Eucharistic Presence, 10, n. 13 and Bakker, La raison et le miracle, 1:21-3 this passage is cited as William's sole address to this topic. 
alters and amplifies both Alexander's account of accidents without a subject and what he himself says in the first passage quoted. Now citing Aristotle via Boethius and Toletanus (that is, Dominicus Gundissalinus) on the hierarchy of the sciences, William notes that metaphysics deals with invisible realities and not with matter and motion. Physics deals with matter and motion. In between these sciences is mathematics. Mathematical realities, like those of metaphysics, are invisible, although we can represent them visibly. These representations include the accidents of the material forms we use in so doing. In no sense do these accidents delimit mathematical realities themselves, which are separable from them, and vice versa. The most basic of these accidents is quantity. Mathematics thus models a rational account of accidents without a subject in the Eucharist: 'Thus we see that the accident of quantity, as in lines, surfaces and the like, is more fully separable from matter than are other substantial forms, such as carnality and the like' (Ex hoc videtur quod accidens, quod est quantitas, ut linea, superficies et huiusmodi, magis sunt separabilia a materia quam aliquae formae substantiales, ut carnalitas et huiusmodi). Since quantity is the accident 'that most greatly approaches and is assimilated to the nature of substance, among accidents it can have per se existence to the highest degree' (ratione qua maxime accedit ad naturam substantiae et illi maxime assimilatur, maxime inter accidentia potest habere esse per se). Quantity subtends the other accidents: 'It is thus said that color, figure, and [other] accidents have quantity as their subject. ( ... ) Quantity, which of all kinds of accidents is the one closest to substance, is the one that is the subject of the others separated from substance' (Dicendum est igitur quod color, figura, et accidentia illa habent quantitatem pro subiecto. ( ... ) Quantitas-eo quod est de genere accidentium propinquissimo substantiaeilla, cum aliis separata a substantia, est subiectum aliorum ( ... )). ${ }^{59}$

William rests his case on this mathematically-derived argument. Having dismissed remanescence traditionally and abruptly, he wields it mainly against annihilation. There is no longer a need to rely on Basil and our possible thought-experiments, or for that matter, on Alexander's theory of sacramental ubiquity based on Christ's divine persona. Rather, William presents his conclusion as a valid application of natural reason to Eucharistic theology. Far from depriving faith of its merit, this argument reinforces it. Yes, like transubstantiation itself, we can describe accidents

59 William of Melitona, De sacramento altaris, p. 6, q. 26, c. 19, 2:619 and 620; q. 26, c. 23b, 2:624 for the passages quoted. For more on this mathematical argument, undermining a preclusive dependence on miracle, see also William of Melitona, De sacramento altaris, p. 6, q. 26, c. 23b, 2:624; q. 27, cc.1-11, 2:628-31; q. 28, c. 13, 2:636. Vijgen, Eucharistic Accidents, 87-94 gives an excellent reprise of this position although he is not interested in its connection with William's critique of annihilation. On the availability of these distinctions among the sciences see Alexander Fidora, 'Die Rezeption der boethianishen Wissenschaftseinteilung bei Dominicus Gundissalinus,' in "Scientia" und "Disciplina": Wissenstheorie und Wissenschaftspraxis im 12. und 13. Jahrhundert, ed. Rainer Berndt et al., Erudiri Sapientia, 3 (Berlin: Akademie Verlag, 2002), 209-22; Mario Ariosio, Aristotelismo e teologia: da Alessandro di Hales a San Bonaventura (Monaco: Liamor, 2012), 19, 28 - 9, 34-5, 37, 52, 455, although Ariosio makes no reference to mathematics or to William of Melitona. 
without a subject as a miracle. But, 'while it can well occur miraculously, it is well true naturally' (bene verum est naturaliter, tamen miraculose bene potest). ${ }^{60}$

Both William of Melitona's argument and this conclusion expressly counter the position of an unnamed but well-known recent master, William of Auxerre. In the prologue to his Summa aurea (1215/29), William of Auxerre states that the application to theology of either natural philosophy or the new semantics of the day is fundamentally unacceptable. Theologians should clarify and defend theological principles known by faith only by reference to other theological principles. William of Auxerre cites as his authority Gregory the Great: if the faith is understood in the light of rational arguments, it loses its merit as a virtue. And, while scholastics often say one thing in their prologues and do something quite different in the body of their works, William of Auxerre sticks to his guns on the Eucharist, simply citing Peter Lombard and John Damascene on the three modes of the Real Presence doctrine and on accidents without a subject while ignoring how these authorities reason to their conclusions. ${ }^{61}$ William of Melitona's defense of the role of reason in Eucharistic theology against this rival position, and the highly original argument he offers in its support in his De sacramento altaris, thus stand out as a signal statement of early Franciscan theological method.

It remains to consider the degree to which the arguments so distinctive of William and of Alexander find their way into Book 4 of the Summa Halensis. Sometimes an author's final work develops and refines his earlier ideas. Sometimes an author's final work shows him running in place. Neither case describes the Summa on the three theories of Eucharistic change and on accidents without a subject. Rather, its Book 4 abridges and dilutes positions earlier taught by William and Alexander, omits arguments of both masters, and introduces arguments contradicting rules which, following Prepositinus, they enforce. The Summa's organization and coverage of Eucharistic topics are odd. Only two of the 32 Quaestiones in Book 4 treat the Eucharist. In between Quaestiones 10 and 11, and occupying some 35 per cent of the space devoted to the Eucharist, William inserts a Tractatus de officio missae recycling Innocent on the prayers of the Mass. But he also places some topics on the administration of the Mass in the middle of Quaestio $10 .^{62}$

60 William of Melitona, De sacramento altaris, p. 6, q. 26, c. 21b, 2:623.

61 William of Auxerre, Summa aurea 1.1-2 (prologus), 4.7.2 (Eucharist), 7 vols, ed. Jean Ribaillier, Spicilegium Bonaventurianum, 16-20 (Paris: Editions du Centre National de la Recherche Scientifique (CNRS); Grottaferrata: Collegium S. Bonaventurae, 1980-7), 1:15-20 and 6:143-47 for these respective passages. See the excellent discussion in Henry Donneaud, Théologie et intelligence de la foi au XIIIe siècle (Paris: Éditions Parole et Silence, 2006), 19-57.

62 Alexander of Hales, Alexandri Alensis Angli Summae Theologiae: Pars Quarta (hereafter, SH Bk IV), vol. 4 (Coloniae Agrippinae: Sumptibus Ioannis Gymnici, sub Monoerote, 1622). The Tractatus de officio missae occupies pages 275-329 in this edition. Other topics of this type derived from Innocent, including who can consecrate, vestments and accoutrements, and the point when transubstantiation occurs during the celebrant's pronunciation of the consecration formula are located in $\mathrm{SH} \mathrm{Bk}$ 
Within Quaestio 10, Membrum 5 treats the three Real Presence theories and Membrum 7 treats accidents without a subject. In contrast with predecessors from the Lombard on, William does not start with transubstantiation-and, be it noted, he never uses this term itself in the Summa. He opens with the inadequacies of remanescence and annihilation on the change (conversio) undergone by the bread and wine, giving these theories equal time. William omits the prefatory semantic clarifications which he and his predecessors stress as criteria for statements about the Eucharist. In dismissing the pertinence of the natural changes derived from Boethius, he omits some from the standard list. Ignoring more recent discussions, his attack on remanescence reiterates Peter Lombard's. The bottom line, for William, is that remanescence is wrong because the full change of the elements in form and matter is supernatural, which the saints confirm. ${ }^{63}$

If this conclusion disposes of remanescence, annihilation and transubstantiation demand new arguments, some of which invoke principles expressly rejected by theologians in William's tradition including William himself. Again reviewing the inadequacy of Boethius on modes of change, William now cites an Aristotelian principle which, he argues, does work for the Eucharist: Created beings are programmed to actualize their natural potentialities. This potency/act dynamic explains the aptitude for change of the Eucharistic bread and wine. These elements basically want to change into something better. Whatever Aristotle might say, this extension of potency and act from plants, as natural phenomena, to bread and wine as fabricated commodities, ignores the theological rationale for the semantics of verbs specified by Prepositinus and Alexander and applied by the earlier William, for the same reason: we must not ascribe agency to the bread and wine. But the Summa does so. William's one nod to current semantic theory is the observation that conversio has a supposition different from annihilatio. Conversio accommodates the retention of an element's accidents, so it is 'unworthy' (indignum) to say that the consecration destroys them: 'On the contrary, by marvelous power its own accidents are saved in it' (immo virtute mirabili salvatur in ipsis accidentibus). ${ }^{64}$ On annihilation, too, William's conclusion awards the palm to supernatural causation.

Along with an appeal to the authority of unspecified saints, William's defense of the full substantial conversio of the elements invokes another Aristotelian principle which may also ascribe agency to them, yoking it to one drawn from mathematics. Just as a line ends in a point, and just as a temporal process ends at some moment in time, so the motion (motus) characterizing change in created beings accounts for the aptitude for change of the Eucharistic elements. That claim aside, here too William reverts to Peter Lombard, with a preemptive envoi to the three theories that recalls Prepositinus: 'The third opinion is that the substance of bread and wine is con-

IV, Q10, M4, Ar1-2, pp. 233-61; SH Bk IV, Q10, M5, Ar1, pp. 261-6; SH Bk IV, Q10, M5, Ar2, pp. 265-75; SH Bk IV, Q10, M5, Ar3, pp. 329-30; SH Bk IV, Q10, M6, Ar1-3, pp. 338-9.

63 SH Bk IV, Q10, M5, Ar3, pp. 329-31.

64 SH Bk IV, Q10, M5, Ar3, pp. 332-3; quotation at 333. 
verted into the body and blood of Christ; this is the truth which the church holds, and reproves other opinions' (Tertia opinio, quod substantia panis \& vini convertitur in corpus \& sanguinem Christi: \& haec est veritas, quam tenet Ecclesia, \& alias opiniones reprobat). ${ }^{65}$

Following this assertion presented as fact, William moves on to accidents without a subject. Here, the Summa walks back from some of his own most innovative arguments but restates others almost verbatim. William opens with Basil, quoted by Alexander but not mentioned in William's earlier work, to underscore God's causative power. True, accidents and substance have different essences. And 'God can separate them without any inappropriateness' (potest Deus sine omni inconvenientia illa separare) ${ }^{66}$ But it is not inappropriate to seek auxiliary explanations. William presents a streamlined version of his mathematical argument for quantity as the prime accident that can exist per se: 'From this it is seen that the accident which is quantity, or lines, surfaces and the like, is more fully separable from matter than are other stable forms' (Ex hoc videtur, quod accidens quod est quantitas, vel linea, superficies \& huiusmodi, magis sunt separabilia a materia, quam aliquae formae stabiles ( ... )). ${ }^{67}$ And so, 'since it is closest to the nature of substance and most fully assimilated to it, quantity, among the accidents, can most fully have being per se' (quod quantitas ratione qua maxime ad naturam substantiae; \& illi maxime assimilatur, \& maxime inter accidentia, potest habere esse per se). ${ }^{68}$ Three important features of William's earlier argument, however, do not survive in the Summa. One is the idea that quantity subtends the other accidents in the consecrated species. Another is that quantity, as an accident inhering in all bodies as such, is shared by all bodies that change into other bodies, including Christ's glorified body. The third is William's defense of natural reason as supporting rather than undermining the merit of faith in the Real Presence.

And so a problem remains. Why, in Book 4 of the Summa Halensis, does William walk back from the most up-to-date and original arguments on Eucharistic theology that he, and Alexander, had developed? As old age, and perhaps illness, supervened, did he run out of steam, suffer memory loss, or have second thoughts? Or, did he envision Eucharistic doctrine in Book 4 of the Summa not as a cutting-edge resource for scholastics-in-training, but as a non-technical guide for confrères preparing to preach and minister to the laity?

Books have their own fortunes, and research to date suggests that the Summa was largely bypassed by Franciscans of the later $13^{\text {th }}$ century interested in the Eucharistic issues treated in this paper. On the issue of accidents without a subject, some Franciscans ignored the Summa and responded directly to the Glossa of Alexander of Hales and to William of Melitona's De sacramento altaris, whether citing their

65 SH Bk IV, Q10, M5, Ar3, pp. 333-7; quotation at 335.

66 SH Bk IV, Q10, M7, Ar1, pp. 340 -4; quotation at 340.

67 SH Bk IV, Q10, M7, Ar1, pp. 342-44; quotation at 342.

68 SH Bk IV, Q10, M7, Ar1, p. 341. 
analysis of the accident of quantity or William's mathematical argument in order to agree or disagree. ${ }^{69}$ They may have taken their cue from Bonaventure, whose regency and lectures on the Sentences began in 1253 and were completed in 1257. Bonaventure's commentary on the Sentences thus overlaps with William's composition of Book 4 of the Summa, and may well have been considered by contemporary Franciscans as superseding it. There are notable departures in Bonaventure from the Summa and, indeed, from the earlier positions of Alexander and William as well. For instance, Bonaventure presents semantic arguments on the Eucharist informed by supposition theory largely as objections to be refuted; it is God's power that gives its force to the consecration formula despite its grammatical defects. ${ }^{70}$ On accidents without a subject and on the accident of quantity, Bonaventure does not support the idea that quantity can subtend the other accidents in the consecrated elements; his own explanation resorts to miracle and the ability of accidents to have essences distinct from substance by their operations. ${ }^{71}$ Some Franciscans of the later $13^{\text {th }}$ century, prior to John Duns Scotus, distanced themselves from the view that the third description of the Real Presence, transubstantiation, was the preferable way to describe it, with Scotus proposing that what changes in the elements is a change in their external relations. ${ }^{72}$

During the later medieval centuries all three positions on the Real Presence doctrine, as well as accidents without a subject and the terminology apposite to the Eucharist, remained in lively contention, informed by the scholastics' increasingly sophisticated metaphysics, logic, and semantic theories. In Stephen Lahey's phrase, this made Eucharistic debates 'the quantum physics of the age'. ${ }^{73}$ Franciscans, and

69 Vijgen, Eucharistic Accidents, 164-70 on Richard Rufus and Walter of Bruges.

70 Bonaventure, On the Eucharist (Commentary on the Sentences, Book IV, dist. 8-13), d. 8, c. 1, qq. 1-3, ed. and trans. Junius Johnson, Dallas Medieval Texts and Translations, 23 (Leuven: Peeters, 2017), 82-6 (Latin), 83-9 (English).

71 Bonaventure, On the Eucharist, d. 10, p. 1, a. 1, q. 2, 160 -1 (Latin), 162-3 (English); d. 12, p. 1, a. 1, q. 1 and q. 3 ad 2, 298-306 (Latin), 299 - 307 (English). As Vijgen, Eucharistic Accidents, 155-9 notes, Bonaventure reiterates Basil's argument on God's ability to do what we can only conceptualize, although without citing him by name.

72 Bakker, La raison et le miracle, 1:43-8, 213, 224-53 on English and continental Franciscans such as John Pecham, William de la Mare, and John Peter Olivi; Adams, Some Later Medieval Theories, $110-5$ on Scotus.

73 Stephen E. Lahey, 'Late Medieval Eucharistic Theology,' in A Companion to the Eucharist in the Middle Ages (see above, n. 45), 499-539; quotation at 539. In addition to titles by Adams, Bakker, and Vijgen cited above see also William J. Courtenay, 'The King and the Leaden Coin: The Economic Background of “sine qua non” Causality,' Traditio 28 (1972): 185-209; reprinted in William J. Courtenay, Covenant and Causality in Medieval Thought: Studies in Philosophy, Theology and Economic Practice (London: Variorum, 1984), ch. 6; Paul J.J.M. Bakker, 'Hoc est corpus meum: L'analyse de la formule de consécration chez les théologiens du XIVe et XVe siècle,' in Vestigia, imagines, verba: Semiotics and Logic in Medieval Theological Texts (XIIIth-XIVth Century), ed. Costantino Marmo (Turnhout: Brepols, 1997), 427-51; Alain de Libera and Irène Rosier-Catach, 'L'analyse scotiste de la formule de la consecration eucharistique,' in Vestigia, imagines, verba, 171-201; Alain de Libera 
others, picked and chose among the philosophical and semiotic resources on offer, in their efforts to ring their own changes on William of Melitona's principle that bene verum est naturaliter, tamen miraculose bene potest. Here, we can only hope that continuing research into the reception of the early Franciscan texts considered in this paper will flesh out the later influence of the Glossa of Alexander of Hales, the De sacramento altaris of William of Melitona, and Book 4 of the Summa Halensis in the development of high medieval Eucharistic theology.

and Irène Rosier-Catach, 'Les enjeux logico-linguistiques de l'analyse de la formule de consecration eucharistique,' Cahiers de l'Institut du Moyen-Âge Grec et Latin 67 (1997): 33-77; Rosier-Catach, La parole efficace (see above, n. 17). 